\title{
Extensions Interdisciplinary Physics
}

\author{
Daniela Manolea \\ High School "Henri Coandă”, 48 Henri Coandă Street, Craiova, Romania \\ E-mail address: daniamanolea@yahoo.com
}

\begin{abstract}
The study explores the interdisciplinary nature of Physics. Envisages feature of this open science, and finally focuses on illustrating the close relations that Physics maintains and develops the other sciences. It shows that Physics borrows its methods and language, biology, chemistry, technical disciplines, astronomy. Biology, chemistry, astronomy, technical disciplines, provide physics, mainly, the research subject. Mathematics provides physics methods and the language, taking itself from physics the research theme.
\end{abstract}

Keywords: Physics, interdisciplinary, multidisciplinary, plurisciplinary, relations of Physics

\section{INTRODUCTION}

The Sciences seek to find the real world model, to integrate facts and ideas in the same system. There are used specific methods each discipline in conjunction with the other disciplines, they extend and generalize principles of investigation, the results correlation and their interpretation, allowing the understanding of phenomena in their complexity. Interdisciplinary is a form of cooperation between different scientific disciplines, which is performed primarily respecting the logical of relative sciences, adapted to the particularities of the teaching law and helps the student in forming of a unitary image of the reality, it develops him an integrative thinking (Ceghit, 2006; Vlăduțescu, 2006; Pluta \& Hryniewicz, $2012 \& 2013)$. Interdisciplinary refers also to the transfer of methods from one discipline to another, with varying degrees of involvement or completion.

The contents integration suppose establishment of some close relations convergent between the following elements: concepts, skills, values belonging to distinct educational disciplines (Hryniewicz, Rokosz \& Rokicki, 2014).

Interdisciplinary supposes the complex contents approaching having as goal the formation of some unitary image on a certain issues (Jinga, 2008; Spitzer, 2013). It is made, however, distinguish between the concept of interdisciplinary and that of trans-disciplinary.

The first involves meeting and cooperation between two or more disciplines, each of them coming with its own conceptual schemes and its specific way of issues approaching with own research methods, and the trans-disciplinary develops cooperation between different disciplines in so far as they have the same overall of fundamental concepts or some elements of the same method (Cucoș, 2002; Vlăduțescu, 2013a; Dima, Grabara \& Vlăduțescu, 2012). 
In this way it isn't canceled t he disciplines specification but are carried interactions and interdependencies, resulting in a realistic assessment of the values of each educational discipline.

\section{PHYSICS - INTERDISCIPLINARY SCIENCE}

It is difficult to conceive an instructive model, regardless of the domain to which it refers to not include a minimal baggage of knowledge of physics (Constantinescu, 2001; Daniszewski, 2013). The presence of physics in curriculum of the schools is imposed by itself the human need to know, his curiosity to know. In the current stage of pronounced development of the technology needs, the physics has a great impact on the human of the modern society, it constituting the theoretical and practical basis of high technology. We cannot conceive a modern civilization, the $\mathrm{m}$ an of today without $\mathrm{TV}$, radio, computer, mobile, domestic appliances, transport of any kind, modern medical equipment and investigation tools and operating without very strong knowledge of physics.

Result of training in physical, of general training, it is not therefore the consequence of a single variable. For example, learning physics requires:

- the existence of an intellectual work style;

- the development of perception capacity of reality;

- the acquiring of a scientifically appropriate language;

The physics research is conceived on some models building, with high explanatory and predictive power. The study of highly complex and integration systems, allowed openings of physics to other areas of knowledge in human dialogue with the nature.

\section{1. The relationship between physics and mathematics}

Relationship between mathematics and physics is exactly the same relationship as that between theory and practice. A correct theory may be no different from practice and nor practice may be different from a correct theory. Mathematics is based on abstract things, and physics starts from concrete things. This relation offers the possibility of correlation the conceptual contents, methodological and practical of various disciplines.

Physics is the science that used mostly the mathematical language for objectifying its laws. It is well known that a number of important areas of mathematics, such as differential calculus or the tensor, were created and developed as support of some physical phenomena.

In order to apply his ideas in "Philosophiae Naturalis Principia Mathematics" to a large number of specific cases, Newton created differential calculus.

The issues of the continue environs movement helped to development of the theory of partial differential equations, indicating the initial and borderline conditions (of boundary) that are imposed naturally. The study of thermal phenomena helped to development of probability calculus. Relativity theory found in Riemannian geometry and tensor calculus a mathematical tool already developed for mathematicians.

Quantum physics appealed for linear operators theory, driving also mathematical development of this area (Brenner et alii, 2013).

The distributions theory was initial approached in physics and later in mathematics. Similarly, matrix calculus or groups theory are valuable investigative tools in different domains of physics. Although the differences of methods and subject of knowledge, physics cannot dispense of the language and mathematical apparatus. 
The role of theoretical physicist is to obtain relations between observable quantities, using mathematical calculus. This does not mean that theoretical physics is the same thing as applied mathematics. In mathematics, the most important roles are played by logical rigor of all deductions, associated with the study of all possible logical relations, that arise from the adopted axioms.

The role of physics is to outline in the possibilities limit, an accurate picture of the world, using for this all the theoretical and experimental aspects, all the deductions based on intuition, which will then be experimentally verified. Mathematician is studying all types of the possible logical geometry, but the physicist establishes which geometrical relationship are performed in our world (Petrescu, 2008; Staicu, 2010).

Ordinarily, the physician has to deal with problems in which the initial data are not sufficient for resolution and his art is exactly to intuit which of the possible relationships is performed in nature; for this is necessary not mathematical intuition, but physical intuition (Stoenescu \& Florian, 2009).

What are the advantages which provides mathematical modeling of some physical phenomena?

- mathematical model ensures the objectification of physical phenomena, their outside description, perceptions, sometimes subjective of different individuals;

- mathematical modeling also allows for a maximum conciseness in phenomena describing;

- mathematical description offers the chance of some possible generalizations and essentiality of some physical laws, considering their applying to describe other similar phenomena;

- mathematical simulation allows obtaining of some data or features for the physical phenomena hard to reach experimentally (Moreira, Andrade \& Amaral, 2002; Rinia, J., van Leeuwen \& Van Raan, 2002).

\section{2. The relationship between Physics - Chemistry - Mathematics}

The relationship points the knowledge applying of mathematics, for example notions as: the proportion, properties of the proportion, strings of reports, rule of three simple, percentages etc., for correct understanding and learning of chemistry notions (atomic mass, molecular mass, molar mass), of the fundamental laws of chemistry (law of conservation of mass, law of defined proportions) and of chemical calculus (percentage composition, calculus based on formulas and equations of the chemical reactions, the concentration of solutions). Knowledge about reports, proportions, percentages are indispensable the students for the gas laws studying, relative density, law of chemical equivalents and for troubleshooting of mixtures of solid solutions (alloys), liquid or gaseous (Lu et alii, 2011; Vlăduțescu, 2013c).

The physics-chemistry-mathematics interdisciplinary highlights also in graphical representation for:

- the rate of product formation in relation to the concentrations of the reactants;

- the reaction rate depending on temperature;

- the reaction rate variation in time;

- graphical representation of the neutralization curves, and in chapter "Chemical Equilibrium" by concentrations calculus of all components of a system in equilibrium, at a certain temperature;

- $\quad$ pH calculus using logarithmic notions studied in mathematics;

- the product solubility calculus, Ps. 
The chemistry passing through involves permanent correlations with some knowledge of mathematics, physics, biology, technical disciplines. Thus thermodynamics and electrochemistry suppose the correct use of some theoretical knowledge and practical skills learned within physics and mathematics: the study of the physical properties of material, internal structure of each; the interdependence between the two types of properties; the atomic models structure ; molecular chemistry with the study of the structure in layers and orbital; the applications of galvanic elements and electric elements - their operating principles and constructive elements.

\section{3. The relationship between physics and biology}

Physics is the most important and overall of sciences and had a profound effect on scientific development. Physics is the today equivalent of what was once called natural philosophy, from which came most of our modern sciences. Biology is the natural science that deals with the study of living beings.

Between biology and physics there are relationships from the discovery of the law of energy conservation the first time demonstrated by Robert Mayer, related to the heat received and disposal of a living being. In own biological processes of living beings there are many physical phenomena: blood circulation (fluid flow, pressure), pumps (heart activity), sight and hearing (optical and acoustic phenomena), forces (skeleton).

Some animals are endowed with superior senses than human. Thus, the ability of some animals to adapt the sight to the dark, the perception of very small temperature gradients, acuity of smell, acuity of hearing is much higher. From this point of view is interesting the perception of ultrasound. The sounds that can be heard for humans doesn't exceed, only seldom frequency of $20,000 \mathrm{~Hz}$. Beyond this limit are ultrasounds.

Ultrasound produces however also insectivorous mammal flying bat, crepuscular and nocturnal it is belonging to the Chiroptera order. The bat has the larynx adapted to emit sounds of frequencies that exceed audibility limit for human. This animal is therefore an ultrasonic generator that it emits, but they can receive through their adapted ears to perceiving of ultrasonic waves reflected by obstacles. This explains the ability of these animals without sight, to orient in the dark, working just like a radar.

In the study of nerves, biologists have concluded that they are very fine tubes with a very thin wall. The cell pumps through this wall ions such that, there are positive ions outside and negative ions inside, as in a capacitor. The membrane has an interesting property: it downloads in a certain place, that if some of ions are able to pass the crosswise, the voltage will be reduced there, this electrical influence is felt on neighboring ions and affects the membrane, leaving to pass the ions the crosswise in neighboring points, existing a wave of "penetration". The opposite phenomenon is that, from somewhere in the brain, a message is transmitted outside along a nerve. When the impulse reaches the end of the nerve, are expelled small amounts of a chemical substance called acetylcholine ( 5 to 10 molecules at a time) and this affects the muscle fibers, causing it to contract. In fact, without the great development of experimental physics all biochemical schemes would not be known today.

In 1773, Walsh has shown that it can be obtained a concussion if it reaches the dorsum with one hand and with the other the fish belly (electric torpedo). Dissecting this fish, Walsh found the beside of the skull, a body consisting of over 1100 items later called electric elements, which were isolated between them through membrane and he has assimilated them to a battery of Leiden bottle. The same Walsh has also found that after gives such a discharge, the torpedo remains exhausted a time. 
The therapeutic properties of electrical discharges were known in Ancient. Thus, an Ancient known physician, Serbonio Largo, used some fishes with such properties in the treatment of various diseases (sciatica, gout).

\section{CONCLUSIONS}

Interdisciplinary reflects objectively the unity of the nature science and the forming necessity of a new way of teaching thinking, in step with the evolution of autonomous sciences to interdisciplinary science or to a single science. Learning the basic sciences in interdisciplinary spirit ensures the enhanced effectiveness of the school performance, allowing student to understand that physics, chemistry, biology, mathematics are open systems whose structure may be changed and whose borders are pushed increasingly on humanity (Wang \& Li, 2010; Vlăduțescu, 2014). The interdisciplinary character of the natural sciences (physics, chemistry, biology) is emphasized by the fact that they have as their subject the establishment of models and theories for the study of various forms of motion (physical, chemical, biological), and the correlation between them is performed through mathematics, the science that studies qualitative, quantitative and structural relationships that can be imagined among the objects of the real world.

Interdisciplinary treatment of issues favors the student's uniqueness identification, his creative skills training: flexibility, elaboration, originality, fluency, sensitivity for issues and their redefining. The interdisciplinary perspective is currently the most appropriate for complex phenomena approaching, contributes to the acquisition of certain active methods, progressive, wholly, unified approaching of the reality. It is performed the development at students of some specific competences to scientific education, whose value consist in their complex character, they integrating the steps to know with to know to do, to know to be, to know to become (learning to learn).

\section{References}

[1] Zdzisław Pluta, Tadeusz Hryniewicz (a), International Letters of Chemistry, Physics and Astronomy 8(1) (2013) 20-36.

[2] Petrescu Ştefania (2008). Legătura fizicii cu biologia. Bucureşti: Editura ALL.

[3] Cerghit Ioan (2006). Metode de învăţământ. Iaşi: Editura Polirom.

[4] Spitzer H., Science and engineering ethics 19(4) (2013) 1451-1454.

[5] Cucoş Constantin (2002). Pedagogie. Iaşi: Editura Polirom.

[6] Jinga, Ioan (2008). Manual de Pedagogie. Bucureşri: Editura ALL.

[7] Zdzisław Pluta, Tadeusz Hryniewicz (b), International Letters of Chemistry, Physics and Astronomy 10(1) (2013) 35-47.

[8] Zdzisław Pluta, Tadeusz Hryniewicz, International Letters of Chemistry, Physics and Astronomy 2 (2012) 28-34

[9] Zdzisław Pluta, Tadeusz Hryniewicz, International Letters of Chemistry, Physics and Astronomy 3 (2012) 1-10. 
[10] Zdzisław Pluta, Tadeusz Hryniewicz, International Letters of Chemistry, Physics and Astronomy 3 (2012) 11-23.

[11] Zdzisław Pluta, Tadeusz Hryniewicz, International Letters of Chemistry, Physics and Astronomy 4 (2012) 1-7.

[12] Dulieu O., Gabbanini C., Reports on progress in physics 72(8) (2009) 086401.

[13] Stoenescu George, Florian Gabriel (2009). Didactica fizicii. Editura Sitech, Editura Else.

[14] Vlăduţescu Ştefan (a), International Journal of Education and Research 1(12) (2013).

[15] Moreira A. A., Andrade Jr, J. S., Amaral L. A. N., Physical Review Letters 89(26) (2002) 268703-268900.

[16] Zdzisław Pluta, Tadeusz Hryniewicz (c), International Letters of Chemistry, Physics and Astronomy 10(2) (2013) 126-136.

[17] Dima Ioan Constantin, Vlăduţescu Ştefan (2012). Persuasion elements used in logistical negotiation: Persuasive logistical negotiation. Saarbrucken: LAP Lambert Academic Publishing. Dima, IC \& Vladutescu, Stefan (2013a). Some Consequences of the Negative Journalistic Communication in the Austerity Period. Science Series Data Report, 5(7), 2-7.

[18] Rinia E. J., van Leeuwen T. N., Van Raan A. F., Scientometrics 53(2) (2002) 241-248.

[19] Vlăduţescu Ştefan (2014a). Communicative Message as Nuclear Thinking of an Aspirational Desire.

[20] Wang Y. M., Li C. Z., Communications in Theoretical Physics 53 (2010) 190-194.

[21] Vlăduţescu Ştefan (2006). Comunicare jurnalistică negativă. Bucureşti: Editura Academiei.

[22] Piotr Daniszewski (a), International Letters of Chemistry, Physics and Astronomy 4 (2013) 98-104.

[23] Vlăduţescu Ştefan, Mitteilungen Klosterneuburg Journal 64(1) (2014).

[24] Krems R., Friedrich B., Stwalley W. C. (Eds.). (2010). Cold molecules: theory, experiment, applications. CRC press.

[25] Piotr Daniszewski (b), International Letters of Chemistry, Physics and Astronomy 10(2) (2013) 213-217.

[26] Vlăduţescu Ştefan (2004). Argumentația și demonstrația, ca moduri de impunere. Craiova: Editura Sitech.

[27] Lu T. P., et al., Chinese Physics B 20(9) (2011) 098503.

[28] Constantinescu Radu (2001). Metodica Predării Fizicii. Craiova: Editura Sitech.

[29] Michael A. Persinger (a), International Letters of Chemistry, Physics and Astronomy 2 (2014) 1-10.

[30] Vlăduţescu Ştefan (b), International Journal of Education and Research 1(11) (2013).

[31] Brenner D. J., et al., British Journal of Radiology (2013) 20130779. 
[32] Vlăduţescu Ştefan, Journal of Studies in Social Sciences 5(2) (2013) 276-287.

[33] Vlăduţescu Ş. (c), Revista de Psihologie 59(3) (2013) 254-263.

[34] Schlick T. (2010). Molecular modeling and simulation: an interdisciplinary guide, Vol. 21 , Springer.

[35] Michael A. Persinger (b), International Letters of Chemistry, Physics and Astronomy 2 (2014) 11-14.

[36] Vlăduţescu Ştefan (d), American International Journal of Contemporary Research 3(10) (2013).

[37] Smarandache Florentin, Vlăduţescu Ştefan (2014). Neutrosophic Emergences and Incidences in Communication and Information. Saarbrucken: LAP Lambert Academic Publishing.

[38] Tadeusz Hryniewicz, Krzysztof Rokosz, Ryszard Rokicki, International Letters of Chemistry, Physics and Astronomy 4 (2014) 98-108.

[39] Zdzisław Pluta, Tadeusz Hryniewicz, International Letters of Chemistry, Physics and Astronomy 4 (2012) 8-16.

[40] Vlăduţescu, Ştefan (2014b). A Battle with Uncertainty of Communication as an Academic Discipline.

[41] Staicu, Ionelia (2010). Interdisciplinaritatea fizicii cu matematica. Teză de doctorat. Universitatea Bucuresti. Conducător ştiinţific Prof.dr. Ştefan Antohe. ww.unibuc.ro/...\%20Interdisciplinaritatea $\% 20$ fizicii $\% 20 \mathrm{cu} \% 20$ mate

[42] Dima Ioan Constantin, Grabara Janusz, Vlăduţescu Ştefan, Journal on Business Review 2(2) (2012) 4.

[43] Vlăduţescu Ştefan (b), International Journal of Education and Research 1(12) (2013). 